\title{
THE URINARY EXCRETION OF IODINE. I. THE LOSS OF IODINE IN THE URINE FOLLOWING THYROIDECTOMY
}

\author{
By GEORGE M. CURTIS AND FRANCIS J. PHILLIPS \\ (From the Departments of Surgery and of Medical and Surgical Research of the \\ Ohio State University. Columbus)
}

(Received for publication April 30, 1934)

\section{INTRODUCTION}

The purpose of this paper is to show that immediately following thyroidectomy for goiter, there ensues a great increase in the urinary excretion of iodine. This may amount to so much as $2.0 \mathrm{mgm}$. during a single twenty-four hour period. Since we have found (1) (2) (3) that the usual urinary excretion of iodine, of our hospital patients, ranges from 0.025 to $0.075 \mathrm{mgm}$. daily, this amounts to a considerable postoperative loss. Subsequently, after periods of varying length, the excretion of iodine in the urine returns to normal.

In investigating iodine metabolism, in patients with goiter (2) (4) (5) we have made routine determinations of the blood and urinary iodine (6). These have been correlated with the clinical findings (4) (5), and, particularly, with the results of the different forms of therapy employed. The data here presented were obtained during the progress of that study.

\section{LITERATURE}

Alexander Sturm (7) determined the urinary excretion of iodine, in dogs, subsequent to total extirpation of the thyroid. He observed a small, but definite, increase in the urinary output of iodine following the thyroidectomy. Curtis and Barron (8) reported a striking postoperative increase in the urinary excretion of iodine, in four patients, subsequent to total thyroidectomy for hypertensive cardiovascular disease in man.

In reporting certain clinical features of the urinary excretion of iodine, Curtis and Phillips (1) noted that the urinary excretion of iodine is greatly increased following partial thyroidectomy for goiter. They also observed an increased urinary loss of iodine after subtotal thyroidectomy for toxic goiter (4) (9). The usual daily loss of iodine, in the urine of normal individuals, is similar to that of University Hospital patients (3).

In reporting the increased urinary excretion of iodine, in patients with toxic goiter, Curtis and Phillips (9) stated that an increased postoperative iodine loss ensues in patients operated upon for causes other than goiter. This was observed in five instances by Curtis and Cole (10). 


\section{OBSERVATIONS}

The pre and post-operative urinary excretion of iodine has been determined in five patients, all thyroidectomized for goiter. These were all maintained upon the Surgical Research Service, in the University Hospital. They were given the usual hospital diet, excluding only those foods known to have a high iodine content (11). Iodized salt is not used in our hospital diets. They were kept at bed rest, and no iodine, in any form, was used or administered throughout their entire management. Their only daily source of iodine was in the food, water, and air intake.

Blood samples, for the blood iodine determinations, were drawn mornings, in the postabsorptive state. Collection of the twenty-four hour urine specimens was made by trained attendants, and was carefully supervised. Analyses of the iodine content of the blood and urine were made after the method of Phillips and Curtis (6). This is an adaptation of the von Fellenberg procedure (14).

Protocols, presenting the principal findings, and the management of each patient, are given, together with corresponding tables and figures which show particularly the urinary excretion of iodine. The five patients each present a different form of goiter: (1) Non-toxic nodular goiter, (2) mildly toxic nodular goiter, (3) toxic nodular goiter, (4) diffuse colloid goiter and (5) exophthalmic goiter. In all five there ensued a definite increase in the urinary iodine loss after thyroidectomy.

\section{Patient 1. Non-toxic nodular goiter (Figure 1)}

B. N., No. 326858, a housewife aged 32, entered the University Hospital December 28, 1933, for thyroidectomy. She had noted a preadolescent goiter, which had slowly become more evident. There had been questionable mild toxic episodes. On December 31 her basal metabolic rate was plus 5 , with the pulse 72 , temperature 98.6 , respirations 15 and blood pressure $105 / 72$, in the basal state. There had been mechanical symptoms, and the trachea was found by $\mathrm{x}$-ray to be deviated. The larynx was normal. The heart was negative.

Laboratory investigation revealed a negative urine, negative Wassermann and Kahn reactions, a secondary anemia and a normal differential count. The blood iodine was elevated, 19 gamma $^{1}$ per cent on December 30, as compared to a normal of 12 (12). The findings of the usual chemical analyses of blood were otherwise within the normal range.

She was prepared for thyroidectomy by rest alone. No iodine was used or administered throughout her management. The daily twenty-four hour urinary excretion of iodine was determined, Figure 1. During the six days preceding the thyroidectomy it remained unusually constant, ranging from 51 to 73 gamma (.051 to $.073 \mathrm{mgm}$.), and averaging 64 gamma $(.064 \mathrm{mgm}$.).

Thyroidectomy was accomplished on January 6 , under nitrous oxide anesthesia. Fifty grams of nodular colloid goiter were removed, leaving a portion estimated as of about 12 grams. The goiter was composed largely of small

1 A gamma is $0.001 \mathrm{mgm}$. (one one-thousandth of a milligram). 19 gamma per cent would be $0.019 \mathrm{mgm}$. in $100 \mathrm{cc}$. of blood. 
colloid nodules, with a moderate amount of internodular substance. There ensued a moderate reaction and an otherwise uneventful convalescence.

During the twenty-four hours subsequent to the thyroidectomy there ensued a great increase in the urinary excretion of iodine, Figure 1. This reached $1.366 \mathrm{mgm}$., or more than twenty times the normal amount. During the following four days it gradually subsided. However, it was greater than usual when the patient was dismissed on January 11,1934 . The average daily urinary excretion of iodine during the five postoperative days was 521 gamma $(0.521$ mgm.). The basal metabolic rate subsequently fell to minus 6 . On January 11 the blood iodine was 16.9 gamma per cent.

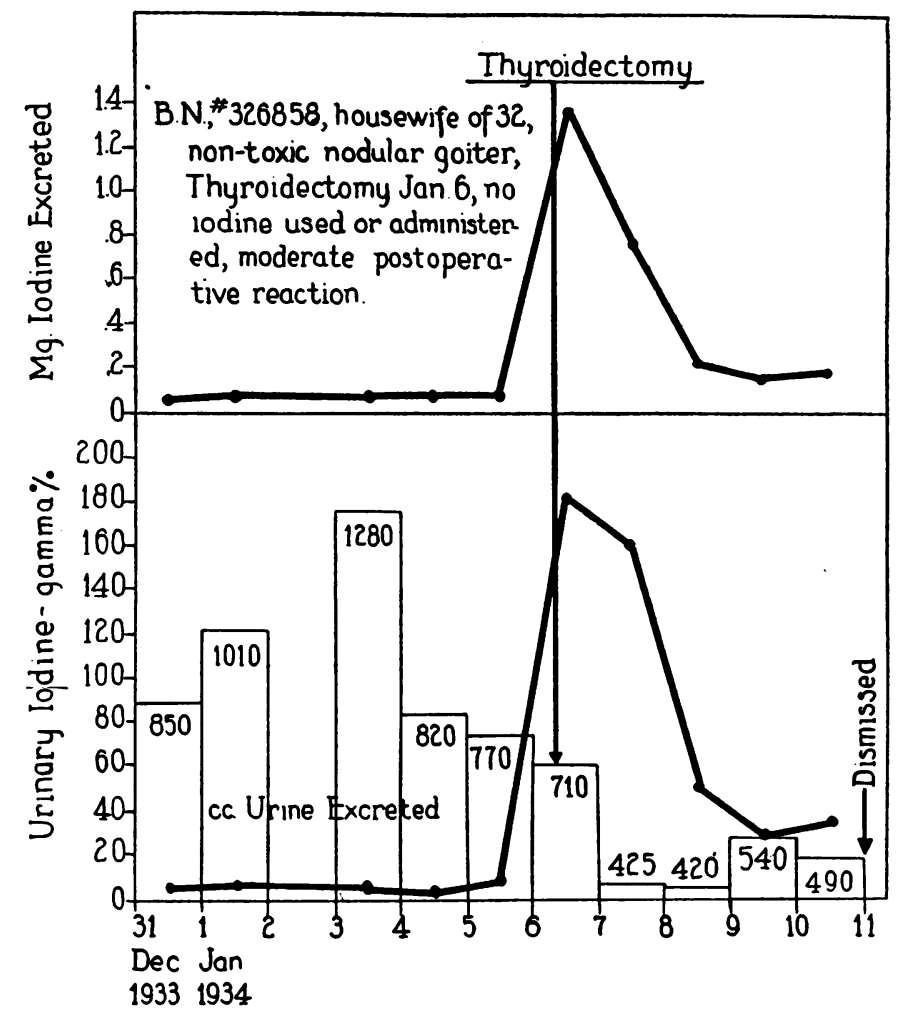

Fig. 1. The Urinary Excretion of Iodine in Non-Toxic NODULAR GoITER

Comment. The preoperative loss of iodine was unusually constant. It was within the normal range. A great increase followed thyroidectomy, and did not return to normal in five days. Following thyroidectomy there ensued a marked increase of the iodine concentration in the urine. The postoperative excretion of urine, however, was diminished.

\section{Patient 2. Mildly toxic nodular goiter (Figure 2)}

D. R., No. 330517, a young woman of 27 , entered the University Hospital, February 2, for thyroidectomy. She had noted a goiter for seven years, and that 
this had gradually increased in size. There had been definite toxic episodes. On February 6, 1934, after four days of bed rest, her basal metabolic rate was plus 18 , with the pulse 92 , the temperature $98.8^{\circ} \mathrm{F}$., the respirations 17 and the blood pressure 130/80 during the basal state. There was some tracheal compression and also $x$-ray evidence of calcification in the goiter. The larynx was normal. The heart was negative, save for a sinus tachycardia.

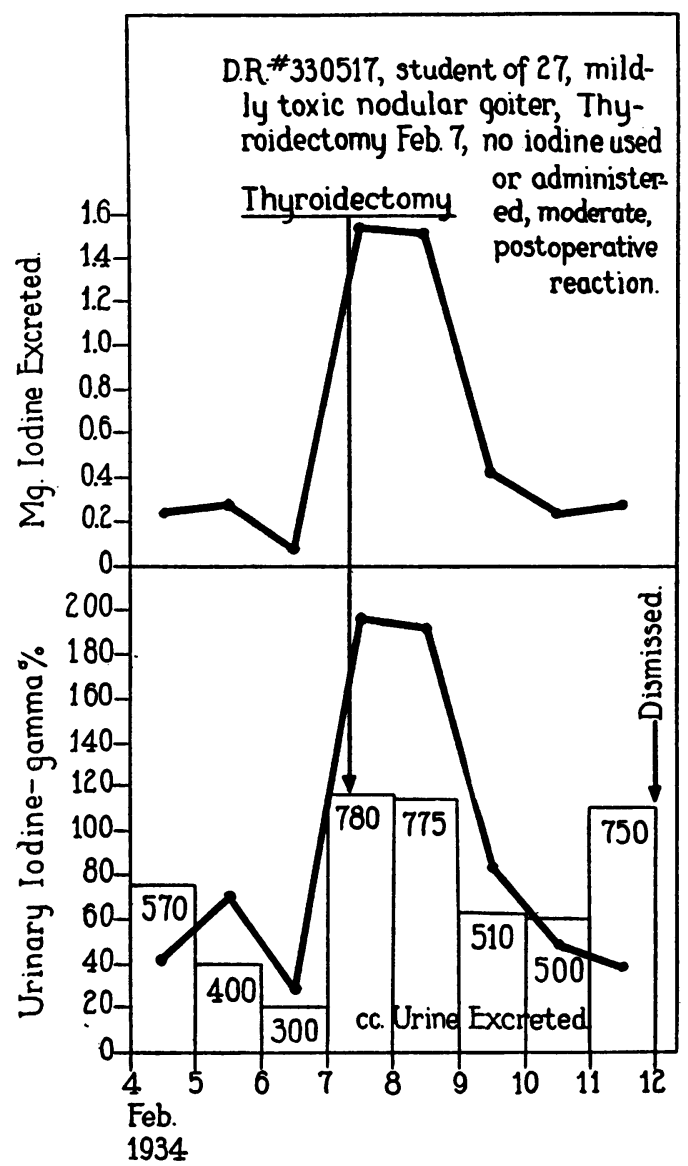

Fig. 2. The Urinary Excretion of Iodine in Mildly Toxic NODULAR GoIter

Laboratory investigation revealed a negative urine, negative Wassermann and Kahn reactions, a moderate secondary anemia and, in the differential count, an increase in the monocytes. The blood iodine on February 6 was elevated, 15.4 gamma per cent, as compared to a normal of 12 . The results of chemical examinations of the blood were otherwise within normal range.

She was prepared for thyroidectomy by bed rest alone, and no iodine was used or administered at any time during her management. The daily preoperative urinary excretion of iodine varied from 85 to 276 gamma (.085 to .276 mgm.), averaging 201 (.201 $\mathrm{mgm}$.). There was an unusual and unexplained 
decrease in the urinary iodine loss during the twenty-four hours preceding the thyroidectomy.

Thyroidectomy was accomplished on February 7 , under nitrous oxide anesthesia. Ninety grams of nodular goiter were removed, leaving a portion estimated as of about 14 grams. The goiter consisted of colloid nodules of varying sizes with a considerable amount of intervening diffuse colloid substance. There was evidence of calcification, fibrosis, hemorrhage, and, microscopically, of " marked colloid involution." No cysts were found. There ensued a moderate reaction and, otherwise, an uneventful convalescence. On the second postoperative day the temperature rose to $103^{\circ} \mathrm{F}$., and the pulse to 126 .

During the 48 hours subsequent to the thyroidectomy there was a striking increase in the urinary excretion of iodine. This averaged $1.5 \mathrm{mgm}$. for the two immediately postoperative days. It then subsided, but was still elevated upon dismissal, February 12 . The basal metabolic rate subsequently fell to minus 10. On February 11 the blood iodine was 13.9 gamma per cent.

Comment. The preoperative excretion of iodine was increased. There occurred a definite decrease just previous to thyroidectomy. The postoperative increase in iodine loss was marked. Subsequent to the first three postoperative days, the amount of urine and the iodine concentration were similar to the preoperative findings.

\section{Patient 3. Toxic nodular goiter (Figure 3)}

C. C., No. 330699, a housewife of 31 , entered the University Hospital, February 10,1934 , for thyroidectomy. Goiter had been originally noted at adolescence. It had become definitely larger during pregnancies. There had been evidence of toxicity for which she had been intermittently given Lugol's solution during the past three years. She had received no iodine for a month previous to this investigation. The basal metabolic rate on January 28 was plus 29 , with the pulse 90 , temperature $98.4^{\circ} \mathrm{F}$., respirations 16 and blood pressure $142 / 78$, in the basal state. The blood iodine on January 28 was increased, to 26.9 gamma per cent.

Laboratory investigation revealed a negative urine, negative Wassermann and Kahn reactions, and a normal blood picture. The heart was negative save for a sinus tachycardia. The trachea and larynx were negative. On February 15 the blood iodine was 21.2. The usual chemical analyses of blood gave normal values.

She was prepared for thyroidectomy by bed rest alone, and no iodine was used or administered throughout the entire management. The daily urinary excretion of iodine was determined, Figure 3. During the eight days preceding the thyroidectomy it ranged from 196 to 415 gamma (.196 to $.415 \mathrm{mgm}$.), averaging 269 gamma $(.269 \mathrm{mgm}$.) daily. Since the average normal daily urinary iodine loss in our hospital patients ranges from 25 to 75 gamma, the urinary excretion of iodine was greatly increased. The increased urinary iodine loss may have been a sequel of the previous administration of Lugol's solution. However, she had received no iodine for one month prior to operation. On February 21 the basal metabolic rate was plus 16, and on February 20 the blood iodine was 11.8 gamma per cent.

Thyroidectomy was performed on February 23, under nitrous oxide anesthesia. Eighty-four grams of nodular goiter were removed, leaving a portion estimated as of about 18 grams. The goiter consisted of many colloid nodules, 
mostly small, with a small amount of internodular glandular tissue. There was evidence of edema, calcification, fibrosis and hemorrhage. Microscopically a "marked lymphocytic infiltration" was noted. There ensued but a slight reaction, and an otherwise uneventful convalescence.

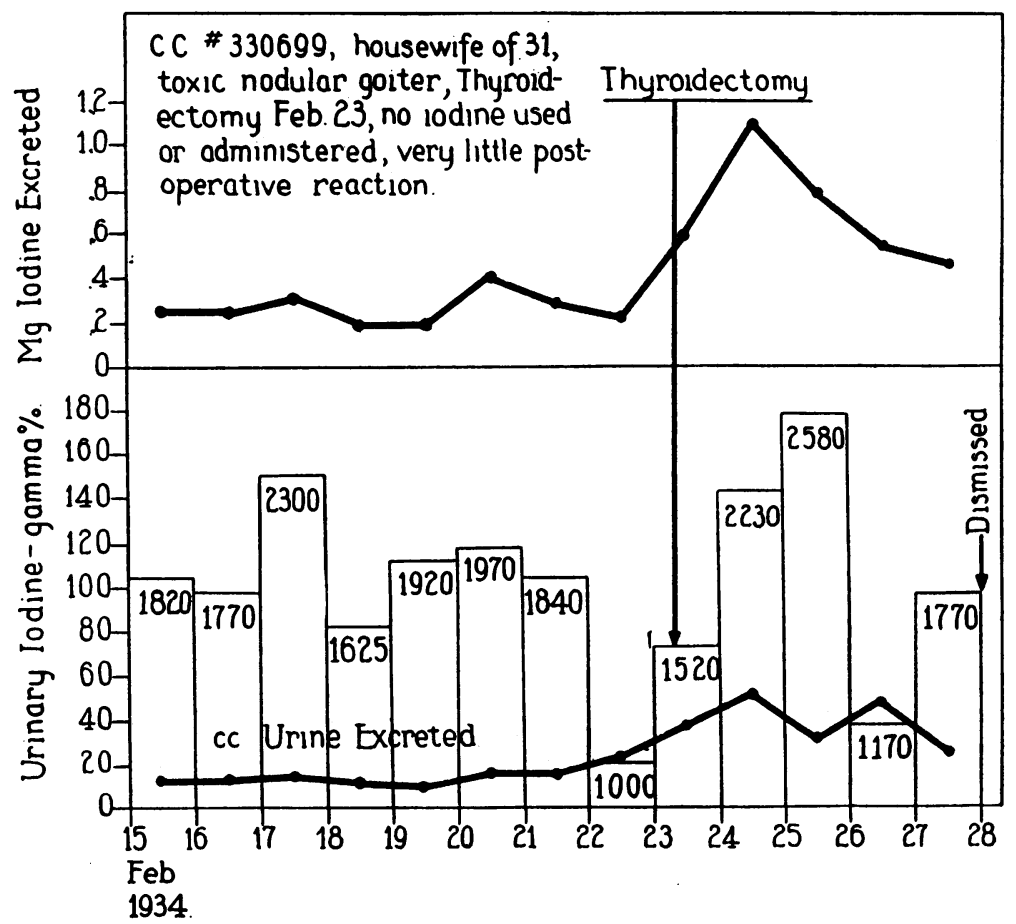

Fig. 3. The Urinary Excretion of Iodine in Toxic Nodular Goiter

The most marked increase in the postoperative urinary excretion of iodine occurred during the second twenty-four hour period, Figure 3. During the five postoperative twenty-four hour periods the iodine loss ranged from 457 to 1117 gamma (.457 to $1.117 \mathrm{mgm}$.), averaging 704 gamma (.704 mgm.). On February 28 , the blood iodine was 9.2 gamma per cent. The basal metabolic rate subsequently fell to minus 4 .

Comment. The preoperative iodine loss was greatly increased. No notable change occurred just preceding the thyroidectomy. The greatest postoperative loss occurred during the second twenty-four hour period. The loss remained high, and did not return to normal in five days. There ensued, following thyroidectomy, an increase in the urinary output and in the iodine concentration.

\section{Patient 4. Diffuse colloid goiter (Table I)}

M. S., No. 330981, a housewife of 29, entered the University Hospital, February 28,1934 , for thyroidectomy. She presented a diffuse symmetrical goiter, 
without nodules, and without thrill or bruit. Goiter had been noted since childhood. It became more evident at puberty. During the past years had occurred a "nervous breakdown," and other episodes suggestive of toxicity. Her symptoms were aggravated during menstruation and after severe emotional excitement. Tachycardia had been noted. Her mother had a goiter. On March 9, after bed rest, her basal metabolic rate was plus 10 (Table $I$ ). There were no pressure symptoms, and the trachea was in normal position by $x$-ray. The larynx and heart were found to be normal.

TABLE I

Twenty-four hour urine iodine in Patient 4

(M. S., No. 330981, housewife of 29 , diffuse colloid goiter, no iodine used or administered, no postoperative reaction, uneventful convalescence)

\begin{tabular}{|c|c|c|c|c|c|c|}
\hline \multirow{2}{*}{ Date * } & \multirow{2}{*}{$\begin{array}{l}\text { Vol- } \\
\text { ume }\end{array}$} & \multirow{2}{*}{$\begin{array}{l}\text { Iodine } \\
\text { gamma }\end{array}$} & \multirow{2}{*}{$\begin{array}{l}\text { Iodine } \\
\text { excreted }\end{array}$} & \multicolumn{2}{|c|}{ Blood iodine } & \multirow{2}{*}{ Remarks } \\
\hline & & & & gamma & Date & \\
\hline $\begin{array}{ll}\text { March } & 1 \\
\text { March } & 2 \\
\text { March } & 3 \\
\text { March } & 4 \\
\text { March } & 5 \\
\text { March } & 6 \\
\text { March } & 7 \\
\text { March } & 8 \\
\text { March } 9 \\
\text { March 10 } \\
\text { March 11 } \\
\text { March 12 } \\
\text { March 13 } \\
\text { March 14 } \\
\text { March 15 } \\
\text { March 16 } \\
\text { March 17 } \\
\text { March 18 } \\
\text { March 19 } \\
\text { March 20 } \\
\text { March 21 }\end{array}$ & $\begin{array}{r}c c . \\
1300 \\
810 \\
1260 \\
1300 \\
860 \\
500 \\
1590 \\
1490 \\
1440 \\
1280 \\
1180 \\
1260 \\
1030 \\
540 \\
875 \\
L 0 s t \\
1280 \\
2150 \\
1120 \\
970\end{array}$ & $\begin{array}{c}\text { per cent } \\
3.2 \\
6.75 \\
2.85 \\
8.3 \\
13.3 \\
9.5 \\
3.6 \\
4.3 \\
2.85 \\
4.3 \\
11.3 \\
11.2 \\
198.0 \\
225.0 \\
65.0 \\
\\
9.2 \\
4.0 \\
4.2\end{array}$ & $\begin{array}{r}m g m . \\
.042 \\
.053 \\
.036 \\
.108 \\
.112 \\
.048 \\
.057 \\
.065 \\
.041 \\
.055 \\
.133 \\
.141 \\
2.030 \\
1.210 \\
.569 \\
\\
.118 \\
\\
.045 \\
.041\end{array}$ & $\begin{array}{c}\text { per cent } \\
16.9 \\
43.0\end{array}$ & $\begin{array}{ll}\text { March } 1 \\
\text { March } 4\end{array}$ & $\begin{array}{l}\text { Menses began March } 3 \text { at } \\
\text { 9:00 a.m. } \\
\text { Menses ended March } 7 \\
\text { Basal metabolic rate on } \\
\text { March } 9 \text { plus 10, pulse } 84, \\
\text { temperature } 98.6, \text { rate } 14, \\
\text { blood pressure 118/68 } \\
\text { Thyroidectomy March } 13 \\
\text { in a.m. }\end{array}$ \\
\hline
\end{tabular}

* 24 hours beginning with date indicated.

Laboratory investigation revealed a normal urine, negative Wassermann and Kahn reactions, a normal blood picture and a normal electrocardiogram. The blood iodine on entrance was 16.9 gamma per cent. The blood calcium was 8.2 and the blood phosphorus was $3.4 \mathrm{mgm}$. per cent. There were no other significant findings.

She was prepared for thyroidectomy by rest alone. No iodine was used or administered throughout the entire management. The daily twenty-four hour excretion of iodine in the urine is presented in Table $I$. This ranged between 36 and 65 gamma daily, save on two occasions. During early menstruation the daily loss was increased to 108 and 112 gamma. Previous to the thyroidectomy there also occurred an increased output, 133 and 141 gamma. The blood iodine 
was elevated to 43.0 gamma per cent during the onset of menstruation. It was 9.7 the morning of the thyroidectomy.

Thyroidectomy was performed on March 13, under avertin-nitrous oxide anesthesia. One hundred grams of diffuse colloid goiter were resected, leaving a portion estimated as of about 18 grams. The goiter was of the same consistency throughout. No nodules were evident. Microscopically it was "struma diffusa colloides, microfollicularis et macrofollicularis." The iodine content of the goiter removed was $56.4 \mathrm{mgm}$. per cent (dry basis). There ensued a moderate reaction and an otherwise uneventful convalescence.

The usual postoperative increase in the urinary excretion of iodine is presented in Table I. Over two milligrams were lost during the twenty-four hours following the thyroidectomy. There ensued a progressive return to normal and during the two days preceding dismissal there was a normal loss of iodine in the urine. The basal metabolic rate subsequently fell to minus 8 . The blood iodine on dismissal, March 21, was 9.4 gamma per cent.

Comment. The preoperative excretion of iodine was within normal range, save in two instances. Once, during menstruation, and again just preceding thyroidectomy, it was increased. A striking iodine loss, followed by a prompt return to normal ensued after thyroidectomy. The behavior of the blood iodine during menstruation is characteristic (13).

\section{Patient 5. Toxic diffuse hyperplastic goiter (Table II). Exophthalmic goiter}

J. B., No. 326974, a housewife aged 32, was originally seen in the Dispensary, in January, 1934, presenting the picture of moderate exophthalmic goiter. At this time her basal metabolic rate was plus 32. Goiter had long been present, and there was evidence of previous toxicity. The present exacerbation of

TABLE II

Twenty-four hour urine iodine in Patient 5

(J. B., No. 326974, housewife of 32, exophthalmic goiter, no iodine used or administered, moderately severe postoperative reaction, uneventful convalescence)

\begin{tabular}{|c|c|c|c|c|c|c|}
\hline \multirow{2}{*}{ Date * } & \multirow{2}{*}{$\begin{array}{l}\text { Vol- } \\
\text { ume }\end{array}$} & \multirow{2}{*}{$\begin{array}{l}\text { Iodine } \\
\text { gamma }\end{array}$} & \multirow{2}{*}{$\begin{array}{l}\text { Iodine } \\
\text { excreted }\end{array}$} & \multicolumn{2}{|c|}{ Blood iodine } & \multirow{2}{*}{ Remarks } \\
\hline & & & & Gamma & Date & \\
\hline $\begin{array}{l}\text { January } 12 \\
\text { January } 13 \\
\text { January } 14 \\
\text { January } 15 \\
\text { January } 16 \\
\text { January } 17 \\
\text { January } 18 \\
\text { January } 19 \\
\text { January } 20 \\
\text { January } 21 \\
\text { January } 22\end{array}$ & $\begin{array}{r}c c . \\
400 \\
650 \\
1380 \\
1250 \\
1900 \\
1650 \\
1880 \\
450 \\
270 \\
480 \\
710\end{array}$ & $\begin{array}{c}\text { per cent } \\
18.8 \\
34.6 \\
9.3 \\
8.9 \\
2.9 \\
57.5 \\
79.6 \\
113.1 \\
74.0 \\
63.7 \\
26.8\end{array}$ & $\begin{array}{r}m g m . \\
.075 \\
.165 \\
.128 \\
.109 \\
.055 \\
.949 \\
1.497 \\
.509 \\
.200 \\
.316 \\
.190\end{array}$ & $\begin{array}{r}20.2 \\
15.5 \\
13.2\end{array}$ & $\begin{array}{l}\text { January } 13 \\
\text { January } 16 \\
\text { January } 18 \\
\text { January } 20 \\
\text { January } 23\end{array}$ & $\begin{array}{l}\text { Subtotal thyroidectomy } \\
\text { January } 18 \text { in a.m. }\end{array}$ \\
\hline
\end{tabular}

* 24 hours beginning with date indicated. 
hyperthyroidism began about three months previously, with the usual symptoms and a severe weight loss. The thyroid was diffusely and symmetrically enlarged. No nodules were palpable: There were no mechanical symptoms.

She was hospitalized on January 4, 1934, and eight days of bed rest preceded this study. No iodine was used or administered throughout her management. On January 6 her basal metabolic rate was plus 40 , with the pulse 96, temperature $99^{\circ} \mathrm{F}$., respirations 17 , and the blood pressure $135 / 75$ during the basal state. The trachea and larynx were normal. The heart revealed only a sinus tachycardia.

Laboratory investigation revealed a normal urine, negative Wassermann and Kahn reactions, essentially a normal blood picture, and an elevated blood iodine. On January 13 the blood iodine was 29.1 gamma per cent. There were no other unusual findings on chemical examination of the blood.

The preoperative urinary excretion of iodine was increased. After a preliminary period of bed rest and adjustment it varied from 55 to 165 gamma daily, during a five day period, averaging 106 gamma per twenty-four hour period. During the twenty-four hours just preceding the operation there was a striking increase, to 949 gamma.

Preparation for thyroidectomy consisted of bed rest alone. Thyroidectomy was accomplished on January 18, using avertin-nitrous oxide anesthesia. Thirty-three grams of vascular, diffuse hyperplastic goiter were resected, leaving a portion estimated as of about 12 grams. The goiter was of the same consistency throughout. No nodules were evident. The cut surface appeared $d r y$, rather than moist as are the cut surfaces of similar goiters after preoperative lugolization. Microscopically the sections revealed the "characteristic diffuse hyperplasia." There ensued a moderately severe reaction followed by an otherwise uneventful convalescence.

During the twenty-four hours subsequent to the thyroidectomy there ensued a great increase in the loss of iodine in the urine, Table II. This gradually subsided during the five days succeeding the thyroidectomy, but was elevated, 190 gamma, on the day of dismissal. The average daily urinary excretion of iodine during the five postoperative days was 543 gamma. During this interval $2.7 \mathrm{mgm}$. of iodine was lost in the urine. The basal metabolic rate subsequently fell to plus 4. The blood iodine on dismissal was 12.5 . It subsequently fell to 10.7 gamma per cent.

Comment. The preoperative loss of iodine in the urine was increased. There was a great increase in the loss just preceding thyroidectomy. This may have been due to the excitement of the impending operation. A greater increase ensued following thyroidectomy. There was a decrease in the output of urine. The behavior of the blood iodine, Table II, is characteristic (2).

\section{COMMENT}

A summary of the preoperative, as compared to the postoperative daily loss of iodine in the urine, is presented in Table III. The average daily loss of the five patients ranges from 0.062 to $0.269 \mathrm{mgm}$. The grand average is $0.171 \mathrm{mgm}$. Following thyroidectomy, the daily loss, at its maximum, is from $1.117 \mathrm{mgm}$. to $2.030 \mathrm{mgm}$. The average daily postoperative loss, of the five patients, ranges from $0.521 \mathrm{mgm}$. to $0.798 \mathrm{mgm}$. 
TABLE III

Loss of iodine in the urine following thyroidectomy

\begin{tabular}{|c|c|c|c|c|c|}
\hline \multirow{2}{*}{$\begin{array}{l}\text { Pa- } \\
\text { tient } \\
\text { numm- } \\
\text { ber }\end{array}$} & \multirow{2}{*}{ Diagnosis } & \multicolumn{2}{|c|}{$\begin{array}{l}\text { Preoperative daily } \\
\text { iodine excretion }\end{array}$} & \multicolumn{2}{|c|}{$\begin{array}{l}\text { Postoperative daily } \\
\text { iodine excretion }\end{array}$} \\
\hline & & Range & $\begin{array}{l}\text { Aver- } \\
\text { age }\end{array}$ & Range & $\begin{array}{c}\text { Aver- } \\
\text { age }\end{array}$ \\
\hline $\begin{array}{l}1 \\
2 \\
3 \\
4 \\
5\end{array}$ & $\begin{array}{l}\text { Non-toxic nodular goiter } \\
\text { Mildly toxic nodular goiter } \\
\text { Toxic nodular goiter } \\
\text { Diffuse colloid goiter } \\
\text { Exophthalmic goiter }\end{array}$ & $\begin{array}{c}m g m . \\
.051 \text { to } .073 \\
.085 \text { to } .276 \\
.196 \text { to } .415 \\
.036 \text { to } .141 \\
.055 \text { to } .949\end{array}$ & $\begin{array}{l}m g m . \\
.064 \\
.201 \\
.269 \\
.074 \\
.247\end{array}$ & $\begin{array}{c}\text { mgm. } \\
1.366 \text { to } .157 \\
1.534 \text { to } .249 \\
1.117 \text { to } .457 \\
2.030 \text { to } .041 \\
1.497 \text { to } .190\end{array}$ & $\begin{array}{l}\text { mgm. } \\
.521 \\
.798 \\
.704 \\
.669 \\
.543\end{array}$ \\
\hline & & $\begin{array}{l}\text { Grand average, } \\
\text { preoperative }\end{array}$ & .171 & $\begin{array}{c}\text { Grand average, } \\
\text { postoperative }\end{array}$ & .647 \\
\hline
\end{tabular}

This grand average is $0.647 \mathrm{mgm}$. It is thus evident, that following thyroidectomy for goiter, there ensues a great increase in the loss of iodine in the urine.

In the three patients with toxic goiter there is a definite increase in the preoperative loss of iodine. We have noted this finding elsewhere (1) (5) (9). The other two show a normal range of urinary excretion of iodine. In Patient 4 there occurred an increase in the iodine loss during menstruation. Cyclic variations of the elevation of the blood iodine, and in the daily loss of iodine in the urine, may occur in women (13).

\section{DISCUSSION}

The source of the excess iodine, lost in the urine subsequent to thyroidectomy, has been of interest. Manipulation of the gland during removal, and absorption from the raw cut-surfaces, were, at first, regarded as likely possibilities. After resection a certain amount of necrosis of the injured areas ensues. The fluid exudate, which collects about the remaining portions of the gland, has a considerable iodine content. Resorption of this may account for some of the iodine loss. On the other hand, an increased urinary loss follows total thyroidectomy (8), in which procedure no raw areas of thyroid are left behind. Manipulation remains an uncontrolled factor in total thyroidectomy.

However, an increased loss of iodine in the urine follows other operations than thyroidectomy, on parts of the body remote from the thyroid (10). Thus, $1.010 \mathrm{mgm}$. was excreted during the twenty-four hour period following an astragalectomy. $1.750 \mathrm{mgm}$. was lost during the first twenty-four hour period following an herniorraphy. 2.515, 2.208 and $3.109 \mathrm{mgm}$. were recovered in the daily urines subsequent to thoracoplasties. 
Altogether, we would consider a tissue loss, extrathyroid in nature, to account, at least for some of the excess iodine excreted. This opens up interesting problems concerning the function of iodine in man. It is possible that iodine has a rôle separate from that of furnishing the high iodine content of the thyroid hormone.

\section{CONCLUSION}

Subsequent to thyroidectomy there ensues a great increase in the loss of iodine in the urine. Evidence at hand warrants the conclusion that a part of this iodine comes from the extra-thyroid tissues.

\section{BIBLIOGRAPHY}

1. Curtis, George M., and Phillips, F. J., The urinary excretion of iodine. J. Clin. Invest. (Proc.), 1933, 12, 963.

2. Curtis, George M., Davis, C. B., and Phillips, F. J., Significance of the iodine content of human blood. J. A. M. A., 1933, 101, 901.

3. Curtis, George M., and Cole, V. V., The normal urinary excretion of iodine. Unpublished study.

4. Curtis, George M., and Phillips, F. J., Newer aspects of the management of hyperthyroidism. Ohio State M. J., 1934, 30, 149.

5. Curtis, George M., Iodine metabolism in toxic goiter. J. Med. (In press.)

6. Phillips, F. J., and Curtis, George M., The clinical determination of iodine in blood, urine and feces. Am. J. Clin. Path., 1934, 4, 346.

7. Sturm, A., Beiträge zur Kentniss des Jodstoff wechsels. Det Jodstoff wechsel des schilddrüsenlosen Hundes. Deutsches Arch. f. klin. Med., 1928, 161, 129.

8. Curtis, George M., and Barron, L. E., The blood iodine after total thyroidectomy in man. Proc. Am. Physiol. Soc., March 30, 1934. (In press.)

9. Curtis, George M., and Phillips, F. J., The urinary excretion of iodine in toxic goiter. J. A. M. A. (Proc. Cen. Soc. Clin. Res., Oct. 27, 1933), 1933, 101, 1992.

10. Curtis, George M., and Cole, V. V., The postoperative loss of iodine in the urine. Unpublished study.

11. Cole, V. V., Curtis, George M., and Bone, M. L., The iodine content of hospital foods. J. Am. Dietet. A. (In press.)

12. Davis, C. B., Curtis, George M., and Cole, V. V., The normal iodine content of human blood. J. Lab. and Clin. Med., 1934, 19, 818.

13. Cole, V. V., and Curtis, George M., Cyclic variations in urinary excretion of iodine in women. Proc. Soc. Exper. Biol and Med., 1933, 31, 29.

14. v. Fellenberg, Th., Das Vorkommen, der Kreislauf, und der Stoffwechsel des Jods. Ergebn. d. Physiol., 1926, 25, 176. 